\title{
Pengaruh Konsentrasi Ekstrak Daun Sirsak Terhadap Penurunan Kualitas Telur Ayam Ras Selama Penyimpanan
}

\author{
The Effect of Soursop Leaf Extract Concentration on Decreasing \\ The Quality of Egg During Storage
}

\author{
Isye Jean Liur \\ Program Studi Peternakan Fakultas Pertanian, Universitas Pattimura, Ambon
}

\begin{abstract}
Hen egg is easy to get and affordable. Besides having a complete nutritional content, chicken eggs are also easily damaged due to microbial activity during storage so that it can reduce egg quality. Therefore, a preservation process is needed to maintain egg quality. This study aims to determine the effect of soursop leaf extract concentrations on decreasing the quality of eggs. This research used a completely randomized design with two factors, the first factor was the concentration of soursop leaf extract $(20,30,40 \%)$ and the second was the shelf life $(0,7,14,21$ and 28 days). Observation included egg white index, egg yolk index, haugh unit, and weights of eggs. The results indicate that eggs with soursop leaf extract immersion treatment can maintain egg quality. The concentration of soursop leaf extract as much as $40 \%$ gives better results in maintaining the quality of eggs.
\end{abstract}

Keywords: hen egg, egg quality, long storages, soursop leaf extract

\begin{abstract}
Abstrak. Telur ayam ras mudah diperoleh dan harganya terjangkau. Selain memiliki kandungan gizi yang lengkap, telur ayam juga mudah mengalami kerusakan akibat adanya aktivitas mikroba selama penyimpanan yang dapat menurunkan kualitas telur. Oleh karena itu diperlukan suatu proses pengawetan untuk menjaga kualitas telur. Penelitian ini bertujuan untuk mengetahui pengaruh konsentrasi ekstrak daun sirsak terhadap penurunan kualitas telur ayam ras selama penyimpanan sampai 28 hari. Penelitian ini menggunakan Rancangan Acak Lengkap dengan dua faktor yaitu faktor pertama adalah konsentrasi dari ekstrak daun sirsak sebanyak 20,30,40\% dan faktor kedua adalah umur simpan telur dalam suhu ruang selama $0,7,14,21$ dan 28 hari. Pengamatan meliputi indeks putih telur, indeks kuning telur, haugh unit dan bobot telur ayam ras. Hasil penelitian menunjukkan telur dengan perlakuan perendaman ekstrak daun sirsak dapat menjaga kualitas telur. Konsentrasi ekstrak daun sirsak sebanyak $40 \%$ memberikan hasil yang lebih baik dalam menjaga kualitas telur ayam ras.
\end{abstract}

Kata Kunci: ekstrak daun sirsak, kualitas telur, lama penyimpanan, telur ayam ras

\begin{abstract}
Aplikasi Praktis. Daun sirsak telah dikenal secara luas karena memiliki banyak manfaat diantarnya mengandung berbagai senyawa yang baik yang dapat dimanfaatkan dalam industri pangan, diantaranya senyawa tanin yang telah dikenal karena memiliki sifat antimikroba sehingga dapat menjaga kualitas bahan pangan. Penelitian ini dapat dijadikan sebagai bahan informasi atau referesi tambahan tentang konsentrasi ekstrak daun sirsak yang baik untuk menjaga kualitas telur ayam ras selama penyimpanan.
\end{abstract}

\section{PENDAHULUAN}

Telur ayam ras selain memiliki kandungan gizi yang sempurna seperti sumber kalori, protein, lemak, vitamin dan mineral, telur juga mudah diperoleh dengan harga yang dapat dijangkau. Umur simpan telur lebih lama beberapa hari dibandingkan dengan daging dan susu karena dilindungi oleh kerabang. Menurut Cornelia et al. (2014), telur segar jika dibiarkan dalam suhu ruang hanya tahan 10-14 hari. Namun demikian, telur memiliki kerabang yang tipis sehingga mudah pecah dan selama penyimpanan dapat terjadi berbagai perubahan baik fisik, kimia maupun mikrobiologi. Menurut Yuwanta

Korespondensi: isye.jean@gmail.com
(2010), kerusakan telur dapat dipengruhi oleh suhu, kelembapan relatif dan kualitas kerabang telur. Perubahan yang terjadi dapat menurunkan kualitas telur. Menurunnya kualitas telur dapat mengakibatkan terjadinya perubahan pada putih telur, kuning telur dan bobot telur. Hasil penelitian Nova et al. (2014), menunjukkan bahwa telur mengalami penurunan mutu dilihat dari haugh unit telur yang semakin menurun dengan nilai 47.69 pada lama penyimpanan 15 hari.

Untuk mengurangi berbagai kerusakan yang berpengaruh terhadap kualitas telur, maka diperlukan suatu metode pengawetan untuk mengurangi menurunnya kualitas telur. Salah satunya adalah metode pengawetan dengan cara merendam telur dalam larutan yang mengandung ekstrak daun sirsak (Annona Muricata L). 
Daun sirsak mudah dijumpai di alam dan memiliki banyak manfaat. Daun sirsak mengandung senyawa tanin yang bersifat antioksidan (Hagerman, 2002). Beberapa penelitian tentang peranan senyawa antioksidan dalam industri farmasi maupun industri pangan telah dilaporkan. Senyawa antioksidan dapat membantu dalam proses pengawetan bahan pangan karena bersifat antimikroba yang dapat memperlambat aktivitas mikroba yang menjadi penyebab kerusakan bahan pangan.

Daun sirsak telah digunakan secara luas dalam industri pangan karena mengandung senyawa tanin. Hasil penelitian Rahman et al. (2017), bahwa daun sirsak mengandung senyawa metabolit sekunder, di antaranya adalah tanin. Dilanjutkan bahwa senyawa tersebut mempunyai kemampuan untuk menghambat aktivitas mikroba. Menurut Wijaya (2012), ekstrak daun sirsak mengandung senyawa tanin yang berfungsi sebagai antibakteri. Hasil penelitian Rahmaningtyas et al. (2012), menemukan bahwa estrak daun sirsak mampu menghambat pertumbuhan bakteri. Dengan demikian daun sirsak berpotensi sebagai pengawet dalam bahan. Perendaman telur dalam larutan yang mengandung ekstrak daun sirsak dengan konsentrasi yang berbeda dapat berpengaruh terhadap kualitas telur karena perbedaan jumlah konsentrasi tanin yang dimiliki. Sehingga diperlukan suatu penelitian yang bertujuan untuk mengetahui konsentrasi ekstrak daun sirsak yang baik dalam mempertahankan kualitas telur ayam ras.

\section{BAHAN DAN METODE}

\section{Bahan}

Daun sirsak sebanyak $4 \mathrm{~kg}$, diambil dari urutan ke 3 sampai ke 5 dari pucuk batang daun. Telur ayam ras yang digunakan adalah telur yang berumur 1 hari sebanyak 60 butir, diambil dari peternak ayam ras di desa hulung, kecamatan pulau Ambon.

Alat yang digunakan antara lain egg tray, kaca datar dengan ketebalan $3 \mathrm{~mm}$, jangka sorong (Mitutoyo, 530104), timbangan digital (Excellent DJ-B), saringan, gelas ukur $1000 \mathrm{~mL}$ (Pyrex), tisu, aquades dan ember plastik sebanyak 4 buah.

\section{Metode}

Daun sirsak sebanyak $4 \mathrm{~kg}$ diblender dengan menggunakan 2 liter air, kemudian disaring untuk memisahkan ampasnya, air yang digunakan bertujuan untuk memudahkan penghancuran daun dengan blender. Dari hasil blender tersebut yang telah dipisahkan dari ampasnya didapat hasil ekstrak daun sirsak. Kemudian larutan ekstrak daun sirsak dengan tambahan akuades dilakukan pembuatan konsentrasi sebanyak 20\% (P1), 30\% (P2) dan 40\% (P3) dan tanpa ekstrak daun sirsak (P0) sebagai pembanding. Setelah itu, telur direndam dalam larutan ekstrak daun sirsak sesuai tiap-tiap konsentrasi selama 24 jam. Kemudian telur diangkat dan ditiriskan hingga kering dan diletakkan pada egg tray kemudian disimpan dalam suhu ruang selama 28 hari. Pengukuran dilakukan mulai dari hari ke $0,7,14,21$ dan 28 hari terhadap indeks putih telur, indeks kuning telur, haugh unit dan bobot telur. Pengukuran dilakukan dengan cara telur dipecahkan kemudian diletakan pada alas kaca yang datar, kemudian telur ditimbang, dan dilanjutkan dengan mengukur tinggi dan lebar albumen maupun yolk menggunakan jangka sorong. Pengukuran dilakukan sebanyak 3 kali sebagai ulangan. Datanya dicatat dan dilanjutkan dengan perhitungan meng-gunakan rumus berdasarkan acuan dari Fibrianti et al. (2012).

\section{Analisis data}

Data yang diproleh kemudian dianalisis secara statistik dengan Rancangan Acak Lengkap (RAL) menggunaakan program SAS versi 9.1. Jika terdapat perbedaan yang nyata dilanjutkan dengan uji Beda Nyata Jujur (BNJ/TUKEY).

\section{HASIL DAN PEMBAHASAN}

\section{Indeks putih telur}

Data hasil penelitian pada Tabel 1, menunjukkan bahwa perlakuan dan lama penyimpanan berpengaruh sangat nyata terhadap indeks putih telur, namun interaksi antara perlakuan dan lama penyimpanan berpengaruh tidak nyata terhadap indeks putih telur. Data menunjukkan bahwa indeks putih telur mengalami penurunan seiring dengan waktu penyimpanan. Perlakuan P1, P2 dan P3 menunjukkan hasil yang lebih baik dibandingkan dengan P0. Penurunan indeks putih telur dapat terjadi karena putih telur yang menjadi semakin encer seiring lama penyimpanan. Pengenceran dapat terjadi karena terjadinya penguapan $\mathrm{HO}_{2}$ dan $\mathrm{CO}_{2}$ di dalam telur. Seperti yang dilaporkan oleh Muchtadi $e t$ al. (2011) bahwa penguapan $\mathrm{CO}_{2}$ menyebabkan pemecahan asam karbon menjadi karbondioksida dan air. Struktur protein musin yang memberi tekstur kental pada putih telur mengalami perubahan sehingga mengakibatkan encernya putih telur. Menurut Ahmadi dan Rahimi (2011), komponen dalam putih telur akan mengalami perubahan seiring lama penyimpanan.

\begin{tabular}{cccccc}
$\begin{array}{c}\text { Tabel 1. Indeks putih telur } \\
\begin{array}{c}\text { Penyimpanan } \\
\text { Hari Ke - }\end{array}\end{array}$ P0 & P1 & P2 & P3 & $\begin{array}{c}\text { Rata- } \\
\text { Rata }\end{array}$ \\
\hline 0 & 0.25 & 0.24 & 0.24 & 0.25 & $0.24^{\mathrm{a}}$ \\
7 & 0.22 & 0.23 & 0.23 & 0.24 & $0.23^{\mathrm{ab}}$ \\
14 & 0.19 & 0.21 & 0.22 & 0.23 & $0.21^{\mathrm{bc}}$ \\
21 & 0.17 & 0.19 & 0.21 & 0.22 & $0.19^{\text {cd }}$ \\
28 & 0.16 & 0.17 & 0.19 & 0.20 & $0.18^{\mathrm{d}}$ \\
\hline Rata-Rata & $0.20^{\mathrm{b}}$ & $0.21^{\mathrm{ab}}$ & $0.21^{\mathrm{ab}}$ & $0.22^{\mathrm{a}}$ & \\
\hline
\end{tabular}

Keterangan: Superscript yang berbeda menunjukkan perbedaan yang sangat nyata $(P>0.05)$

Perendaman telur dalam larutan yang mengandung ekstrak daun sirsak dapat menjaga kualitas albumen, hal ini dapat dilihat dari perlakuan P3 dengan lama penyimpanan sampai 28 hari, dimana indeks putih telur 
mengalami penurunan yang tidak terlalu jauh dari 0.25 menjadi 0.20 , dibandingkan perlakuan P0, yang mengalami penurunan dari 0.25 menjadi 0.16 pada lama penyimpanan 28 hari. Larutan ekstrak daun sirsak dapat menghambat terjadinya penguapan air dan gas. Kandungan tanin dalam ekstrak daun sirsak dapat menghambat keluarnya gas dan mencegah masuknya mikroba. Semakin banyak kandungan tanin yang digunakan maka semakin sedikit terjadinya penguapan. Kandungan tanin dengan sifat antimikroba dapat menjaga kualitas telur.

\section{Indeks kuning telur}

Data hasil penelitian pada Tabel 2, menunjukkan bahwa perlakuan dan lama penyimpanan berpengaruh sangat nyata terhadap indeks kuning telur, interaksi antara perlakuan dan lama penyimpanan juga berpengaruh sangat nyata terhadap kuning telur. Data hasil penelitian menunjukkan terjadinya penurunan indeks kuning telur selama penyimpanan. Namun demikian perlakuan P1, P2 dan P3 memiliki penurunan yang lebih lambat dibandingkan dengan tanpa perlakuan (P0). Penurunan indeks kuning telur dapat disebabkan oleh adanya transfer air dari putih telur, dimana kuning telur dapat menyerap air dari albumen, dengan menyerap air dari albumen dapat menyebabkan kenaikan volume kuning telur, sehingga indeks kuning telur semakin menurun. Menurut Koswara (2009), indeks kuning telur segar berkisar antara 0.33-0.50. Data pada Tabel terlihat bahwa indeks kuning tergolong baik sampai pada 28 hari penyimpanan dengan perendaman pada ekstrak $40 \%$. Perendaman dalam ekstrak daun sirsak dapat memperlambat menurunnya indeks kuning telur selama penyimpanan. Semakin banyak kandungan senyawa tanin dalam daun sirsak, semakin menghambat penurunan indeks kuning telur.

Tabel 2. Indeks kuning telur

\begin{tabular}{cccccc}
\hline $\begin{array}{c}\text { Penyimpanan } \\
\text { Hari Ke - }\end{array}$ & P0 & P1 & P2 & P3 & $\begin{array}{c}\text { Rata- } \\
\text { Rata }\end{array}$ \\
\hline 0 & $0.52^{\text {ab }}$ & $0.50^{\text {abc }}$ & $0.50^{\text {abc }}$ & $0.53^{\mathrm{a}}$ & $0.51^{\mathrm{a}}$ \\
7 & $0.40^{\mathrm{de}}$ & $0.45^{\mathrm{bcd}}$ & $0.49^{\mathrm{abc}}$ & $0.52^{\mathrm{ab}}$ & $0.46^{\mathrm{a}}$ \\
14 & $0.31^{\mathrm{gh}}$ & $0.34^{\mathrm{ef}}$ & $0.40^{\mathrm{de}}$ & $0.43^{\mathrm{cd}}$ & $0.37^{\mathrm{b}}$ \\
21 & $0.25^{\mathrm{gh}}$ & $0.31^{\text {gh }}$ & $0.33^{\mathrm{efg}}$ & $0.39^{\text {def }}$ & $0.32^{\mathrm{b}}$ \\
28 & $0.14^{\mathrm{i}}$ & $0.24^{\mathrm{h}}$ & $0.25^{\mathrm{gh}}$ & $0.34^{\text {ef }}$ & $0.24^{\mathrm{c}}$ \\
\hline Rata-Rata & $0.32^{\mathrm{b}}$ & $0.37^{\mathrm{ab}}$ & $0.39^{\mathrm{ab}}$ & $0.44^{\mathrm{a}}$ & \\
\hline
\end{tabular}

Keterangan: Superscript yang berbeda menunjukkan perbedaan yang sangat nyata $(P>0.05)$

Menurut Muchtadi et al. (2011), aliran air secara terus-menerus melewati membran vitelin dari albumen ke bagian yolk dapat menyebabkan membesarnya bagian yolk akibat terjadinya penurunan elastisitas membran vitelin. Namun dengan perendaman telur dalam ekstrak daun sirsak dapat menghambat laju transfer air karena kandungan tanin dalam daun sirsak bereaksi dengan protein pada kerabang telur dan membentuk lapisan yang bersifat impermeable sehingga menghambat terjadinya penguapan air dan gas.

\section{Haugh unit (HU)}

Data hasil penelitian pada Tabel 3, menunjukkan bahwa perlakuan dan lama penyimpanan berpengaruh sangat nyata terhadap nilai haugh unit, demikian juga dengan interaksi antara perlakuan dan lama penyimpanan terhadap nilai haugh unit. Tingkat kesegaran telur sering dihubungkan dengan nilai haugh unit, dimana nilai haugh unit yang tinggi menunjukkan telur memiliki kualitas yang baik. Nilai haugh unit juga berhubungan dengan tinggi albumen pada putih telur. Data hasil penelitian menunjukkan bahwa semakin lama penyimpanan dapat menurunkan nilai haugh unit. Hal ini diduga karena terjadi penguapan air dan $\mathrm{CO}_{2}$. Penguapan yang terjadi juga berpengaruh terhadap kekentalan putih telur. Nilai haugh unit semakin rendah karena putih telur yang semakin encer. Konsentrasi tanin yang sedikit menyebabkan pengenceran terjadi lebih cepat dibandingkan dengan konsentrasi $30 \%$ pada perlakuan P3. Menurut Djaelani et al. (2019), putih telur menjadi encer karena terjadinya penguapan, berkurangnya kemampuan mengikat protein dan kadar fosfor yang bertambah sehingga dapat menurunkan nilai haugh unit. Putih telur yang kental berhubungan dengan kandungan ovomucin, dimana apabila terjadi kerusakan pada ovomucin dapat menyebabkan keluarnya air dari protein putih telur. Hal ini sesuai dengan pernyataan Andi (2013) bahwa, nilai haugh unit dipengaruhi oleh kandungan ovomucin pada putih telur.

Tabel 3. Haugh unit

\begin{tabular}{|c|c|c|c|c|c|}
\hline $\begin{array}{c}\text { Penyim- } \\
\text { panan } \\
\text { Hari Ke - }\end{array}$ & PO & P1 & P2 & P3 & $\begin{array}{l}\text { Rata- } \\
\text { rata }\end{array}$ \\
\hline 0 & $58.62^{a b}$ & $58.72^{a b}$ & $58.64^{a b}$ & $58.46^{\mathrm{a}}$ & $58.61^{a}$ \\
\hline 7 & $56.91^{\mathrm{abc}}$ & $57.19^{\mathrm{ab}}$ & $57.24^{\mathrm{ab}}$ & $57.97^{\mathrm{ab}}$ & $57.32^{\mathrm{ab}}$ \\
\hline 14 & $56.08^{\mathrm{cd}}$ & $56.16^{\mathrm{abc}}$ & $56.42^{\mathrm{ab}}$ & $56.8^{\mathrm{ab}}$ & $56.36^{\mathrm{abc}}$ \\
\hline 21 & $54.78^{d}$ & $55.44^{\mathrm{bc}}$ & $56.02^{\mathrm{ab}}$ & $56.51^{\mathrm{ab}}$ & $55.68^{b c}$ \\
\hline 28 & $54.41^{d}$ & $54.77^{\mathrm{cd}}$ & $55.08^{\mathrm{bc}}$ & $55.65^{\mathrm{ab}}$ & $54.97^{\mathrm{c}}$ \\
\hline Rata-Rata & $56.16^{C}$ & $56.46^{b}$ & $56.68^{\text {ab }}$ & $57.08^{a}$ & \\
\hline
\end{tabular}

Keterangan: Superscript yang berbeda menunjukkan perbedaan yang sangat nyata $(P>0.05)$

Data pada Tabel 3, menunjukkan bahwa P3 memiliki nilai haugh unit terbesar setelah disimpan sampai hari ke 28. Namun demikian, keseluruhan nilai haugh unit hasil pengamatan hari ke 0 sampai pada hari ke 28 tergolong baik dengan rata-rata berkisar antara 56.1657.08. Menurut Sarwono (2001), nilai haugh unit tergolong baik, apabila berada pada kisaran 31-60. Berdasarkan data yang ada maka dapat dikatakan bahwa konsentrasi senyawa tannin dapat menjaga kualitas telur. Tanin dapat membentuk ikatan hidrogen dengan protein sehingga dapat mengganggu kehidupan mikroba, dengan sifatnya sebagai antimikroba tersebut maka tanin dapat berfungsi sebagai pengawet karena dapat menghambat aktivitas mikroba yang menyebabkan kerusakan terhadap suatu bahan pangan.

Hasil pengamatan menunjukkan P3 memiliki nilai HU yang lebih tinggi dibandingkan perlakuan lainnya sehingga dapat menjaga kualitas telur dengan lebih baik. Menurut Yulianto (2011), senyawa tanin dapat menyebabkan protein yang berada dipermukaan kulit telur menggumpal dan menutupi pori-pori telur. Senyawa 
tanin yang menutupi pori-pori telur dapat memperlambat penurunan nilai indeks putih telur yang berpengaruh juga terhadap nilai haugh unit.

\section{Bobot telur}

Data hasil penelitian pada Tabel 4, menunjukkan bahwa perlakuan dan lama penyimpanan berpengaruh sangat nyata terhadap bobot telur sedangkan interaksi antara perlakuan dan lama penyimpanan tidak berpengaruh nyata terhadap bobot telur. Data hasil penelitian dapat terlihat bahwa, bobot telur semakin menurun seiring lamanya penyimpanan.

Tabel 4. Bobot telur

\begin{tabular}{cccccc}
$\begin{array}{c}\text { Penyimpa- } \\
\text { nan Hari Ke - }\end{array}$ & P0 & P1 & P2 & P3 & $\begin{array}{c}\text { Rata- } \\
\text { rata }\end{array}$ \\
\hline 0 & 61.12 & 62.34 & 62.04 & 62.1 & $61.9^{\mathrm{a}}$ \\
7 & 58.99 & 59.82 & 60.79 & 61.81 & $60.35^{\mathrm{a}}$ \\
14 & 58.36 & 58.98 & 60.88 & 61.81 & $60.00^{\mathrm{a}}$ \\
21 & 56.88 & 58.12 & 59.47 & 61.23 & $58.92^{\mathrm{b}}$ \\
28 & 54.9 & 57.07 & 57.66 & 60.05 & $57.42^{\mathrm{c}}$ \\
\hline Rata-Rata & $58.05^{\mathrm{b}}$ & $59.26^{\mathrm{ab}}$ & $60.168^{\mathrm{ab}}$ & $61.434^{\mathrm{a}}$ & \\
\hline
\end{tabular}

Keterangan: Superscript yang berbeda menunjukkan perbedaan yang sangat nyata $(P>0.05)$

Setelah mengalami penyimpanan selama 28 hari terlihat bahwa penurunan bobot telur semakin lambat seiring bertambahnya konsentrasi ekstrak daun sirsak. Kerusakan terjadi akibat adanya aktivitas mikroorganisme sehingga berpengaruh terhadap bobot telur. Semakin lama telur disimpan, maka kerusakan yang terjadi juga semakin besar sehingga berpengaruh terhadap penurunan bobot telur. Menurut Winarno (2004), semakin lama penyimpanan maka jumlah bakteri akan meningkat.

Kehilangan bobot telur juga dapat disebabkan adanya penguapan air dan $\mathrm{CO}_{2}$ yang terjadi sehingga berakibat terhadap kehilangan bobot. Penguapan air dan $\mathrm{CO}_{2}$ selama penyimpanan juga berpengaruh terhadap penurunan nilai indeks putih telur dan kuning telur yang berakibat terhadap penyusutan bobot telur. Berkurangnya bobot telur akan terus berlangsung seiring bertambahnya waktu simpan sampai dikonsumsi. Seperti dikatakan oleh Buckle et al. (2009), bahwa penguapan air dan gas-gas dari putih telur dapat terjadi selama penyimpanan dan menyebabkan terjadinya penyusutan bobot telur. Dilanjutkan oleh Ukwu et al. (2017), bobot telur dipengaruhi oleh pengukuran tinggi dan diameter kuning telur. Bobot telur normal berkisar antara 58-75, sehingga dari data pengamatan dapat dikatakan bahwa bobot telur masih tergolong baik sampai penyimpanan hari ke 28, dimana perlakuan dengan konsentrasi tanin sebanyak $40 \%$ dapat menjaga bobot telur dan kualitas telur setelah disimpan selama 28 hari, seperti hasil penelitian oleh Kartina (2017) bahwa konsentrasi tanin dalam daun sirsak dapat membantu dalam proses pangawetan telur.

\section{KESIMPULAN}

Konsentrasi ekstrak daun sirsak $40 \%$ dapat menghambat penurunan kualitas telur ayam ras selama penyimpanan sampai 28 hari.

\section{DAFTAR PUSTAKA}

Ahmadi F, Rahimi F. 2011. Factors affecting quality and quantity of egg production in laying hens: A Review. World Appl Sci J 12(3): 372-384.

Andi NM. 2013. Pengaruh Level Ekstrak Daun Melinjo (Gnetum gnemon Linn) dan Lama Penyimpanan Yang Berbeda Terhadap Kualitas Telur. [Skripsi]. Sekolah Sarjana, Universitas Hasanuddin. Makassar.

Buckle KA, Edward RA, Fleet GH, Wootton M. 2009. Ilmu Pangan. Terjemahan Hari $\mathrm{P}$ dan Adiono. Jakarta: UI Press. ISBN: 979789376738.

Cornelia A, Suada IK, Rudyanto MD. 2014. Perbedaan daya simpan telur ayam ras yang dicelupkan dan tanpa dicelupkan larutan kulit manggis. Indonesia Medicus Veterinus 3(2): 112-119.

Djaelani MA, Novika Z, Azizah N. 2019. Pengaruh pencucian, pembungkusan dan penyimpanan suhu rendah terhadap kualitas telur ayam ras (Gallus L). Bulletin Anatomi Fisiologi e-Journal 4(1): 29-34.

Fibrianti SM, Suada IK, Rudyanto MD. 2012. Kualitas telur ayam konsumsi yang dibersihkan dan tanpa dibersihkan selama penyimpanan suhu kamar. Indonesia Medicus Veterinus 1(3): 408-416.

Hagerman AE. 2002. Tannin Handbook. Department of Chemistry and Biochemistry, Miami University. Miami.

Kartina. 2017. Pengaruh Konsentrasi Ekstrak Daun Sirsak Sebagai Pengawet Telur Ayam Rasdan Umur Telur Terhadap Kualitas Organoleptik. [Skripsi]. Makassar: Sekolah Sarjana, Universitas Hasanuddin, Makassar.

Koswara S. 2009. Teknologi Pengolahan Telur (Teori dan Praktek). eBookPangan.com.

Muchtadi TR, Sugiyono, Ayustaningwarno F. 2011. Ilmu Pengetahuan Bahan Pangan.Penerbit Alfabeta. Bandung. ISBN: 978-602-8800-13-6.

Nova I, Kurtini T, Veronica W. 2014. Pengaruh lama penyimpanan terhadap kualitas internal telur ayam ras pada fase produksi pertama. J Ilmiah Peternakan Terpadu 2(2): 16-21. DOI: 10.23960/jipt.v2i2.p\% $25 \mathrm{p}$.

Rahman FA, Haniastuti T, Utami TW. 2017. Skrining fitokimia dan aktivitas antibakteri ekstrak etanol daun sirsak (annona muricata 1.) pada Streptococcus mutans ATCC 35668. Kedokteran Gigi Indonesia 3(1): 1-7. DOI: 10.22146/majkedgiind.11325. 
Rahmaningtyas R, Nashrianto H, Aminingsih T. 2012. Idenifikasi Senyawa Dalam Ekstrak Etanol dan Fraksi Etil Asetat Daun Sirsak Naga (Drymoglossum piloselloides) dengan GC-MS dan Uji Aktivitas Antibakteri. [Skripsi]. Bogor. Fakultas Matematika dan Ilmu Pengetahuan Alam, Universitas Pakuan, Bogor.

Ukwu HO, Ezihe CO, Asaa SK, Anyogo ME. 2017. Effect of egg weight on enternal and internal egg quality traits of isa brown egg layer chickens in Nigeria. An Sci Vet Med J 2(4): 126-132. DOI: 10.31248/JASVM2017.051.
Wijaya M. 2012. Ekstraksi Annonaceous Acetogenin dari Daun Sirsak, Annona Mucirata, Sebagai Senyawa Bioaktif Antikanker [Skripsi]. Fakultas Kedokteran Universitas Indonesia.

Winarno FG. 2014. Kimia Pangan dan Gizi. PT. Gramedia Pustaka Utama. Jakarta. ISBN: GM-2184.013.

Yuwanta T. 2010. Telur dan Kualitas Telur. Gadjah Mada University Press. Yogyakarta. ISBN: 979420-726-8.

JMP-08-20-11-Naskah diterima untuk ditelaah pada 8 Agustus 2020. Revisi makalah disetujui untuk dipublikasi pada 13 September 2020. Versi Online: http://journal.ipb.ac.id/index.php/jmpi 